\title{
Magnetic resonance cholangiopancreatography (MRCP)
}

有山襄

要旨

MRCPは無侵襲で造影剂を使用することなく，膵胆道が描出できる方法である．原理は強いT2 強 調画像を撮像すると, 静止液体である胆汁と苹液は高信号, 周囲臓器の肝・膵などは低信号に描出さ れ, 2 次元， 3 次元で画像を再構成するとERCPと同様の像がえられる。機器の進歩によって短時間で 空間分解能の良好な画像がえられるようになり，臨床で広く応用されるようになった，MRCPは超音

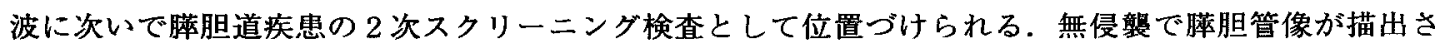
れるので, 患者にとって福音である. ERCPが施行困難な症例でも容易に㬸胆管像がえられ，膵胆管 閉塞部の上流と下流が描出される特徴があり，膵胆道疾患の早期診断にきわめて有効である. われわ れの施設ではMRCP導入後, 診断的ERCPの件数が大幅に減少した。

[日内会誌 $88 ： 1349 \sim 1353 ， 1999$ ]

Key words : MRCP, 膵胆道疾患, 診断, 治療

\section{はじめに}

Magnetic resonance cholangiopancreatography（MRCP）は無侵襲で造影郕を使用するこ となく，萊胆道が描出できる方法である．原理 は強いT2強調画像を撮像すると, 静止液体で ある胆汁と膵液は高信号, 周囲臓器の肝・膵な どは低信号で描出され，2 次元，3 次元で画像 を再構成すると内視鏡的莝胆管造影 (ERCP) と同様の像がえられる．機器の進歩によって短 時間で空間分解能の良好な画像の撮影が可能に なり，臨床に広く応用されるようになった。

\section{MRCPの特徵}

MRCPはERCP, 経皮経肝胆道造影 (PTC) などの在来の苏胆道造影法に比べて以下の利点
がある。

1）まったく侵襲がない.

2）造影剤を必要としない.

3）合併症がない.

4）前処置が不要である.

5）術者の熟練を要さない.

6）経静脈性胆道造影のように生理機能に影 響されない。

7）閉塞部の上流の腪胆管が描出される.

8）急性粨炎，胆管炎の症例にも施行できる.

9) Billroth I法などの消化管再建術後, 上部 消化管通過障害の患者に施行可能である。

短所として以下のものがあげられる。

1）直接造影に比べて空間分解能が悪く, 細 い分枝がみえない。

2）肥満, 腹水の症例では画像が劣化する.

3）治療手技が行えない.

ありやま .どょう：順天堂大学消化器内科 


\section{MRCPの歴史と進歩}

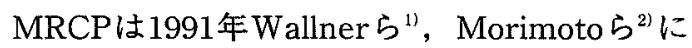
よって初めて報告された. 撮像法として steady state free procession（SSFP）を用いたが，空 問分解能が悪く正常の腪胆道の描出は困難で あった.1994年にTakeharaら゙は はecho trainを 延長したfast spin echo（FSE）法で表面コイル を使用して慢性腪炎の拡張した膵管の描出に成 功した. SSFP法に比べると空間分解能は改善 されたが，呼吸停止時間が20秒〜1分と長く, motion aritifactによって正常膵管の描出は難し かった. Sotoら"はMRIの呼吸同期法を用いて 画像の改良を試みたが，正常莘管の描出率は低 かった. FSE法では画像再構成に最大值投影法 （maximum intensity projection $=$ MIP）を用い るため再構成の際にartifactが起こり，莝胆管 の狭窄や陰影欠損のfalse positiveが多かっ た5).

1995年, Laubenberger $ら^{6}$ はrapid acquisition by relaxation enhancement technique (RARE) 法で, 1回の電磁波の放射で撮像する single shot によって強いT2強調画像を 4 秒で得ることに 成功した。さらにフーリエ変換を改良したhalfFourier acquisition single-shot turbo spin echo $(\text { HASTE })^{7)}$, fast advanced spine echo (FA$\mathrm{SE})^{8)}$ を用いることにより撮像時間は 2 秒に短 縮された。 single shot法では呼吸停止時間が短 く, motion artifactが少なく, 画像再構成は 2 次元 (2D) で行われ 3 次元 (3D) 構成である MIPが必要ないために再構成によるartifactも 減少した。さらに新しい表面コイル，脂肪抑制 法が開発され空間分解能が向上して, 正常膵胆 道の描出率が著明に向上した，検查は外来で簡 便に行えるようになり，臨床検査として確立さ れた。

\section{3. 撮像法}

検查前 $4 \sim 6$ 時間絶食とする.検査直前にferric ammonium citrate（フェリセルツ）1000mg を50〜 $80 \mathrm{ml}$ の水に溶解して服用させ, 胃十二 指腸内容液を低信号化させて, 荤胆管像との重 なりを防ぐ.

$2 \mathrm{D}$ では冠状断, 第 $1 \cdot 2$ 斜位, 横断像を撮像 して病変部の描出に最適な断面を決定する. 3 Dでは撮像によって収集したデータをmaximum intensity projection (MIP) 法によって 処理する.MIPは視点と投影面を結ぶ線上で最 大輝度を表示して, いろいろな角度からみた投 影像を作成する方法で, 画像を左右前後に回転 させて立体的に病変をみることができる.

$2 \mathrm{D}$ と $3 \mathrm{D}$ 画像の比較を表に示す. 2Dは撮像時 間が短く，スクリーニング検查に適している. 3Dは画像が明瞭で，いろいろな方向から病変 をみることができるので, 精密検查として行わ れる場合が多い.

\section{MRCPの正常膵胆道描出率}

ERCPで確認された正常の肝外胆管のMRCP の描出率はほぼ100\%，胆襄90〜100\%，胆霊管 $75 \sim 90 \%$, 肝内胆管区域枝 $90 \%$ と良好な成績が 報告されている 100\%, Santorini管93\%，膵管分枝75～90\%であ る $^{10)}$.

表. MRCP : 2D vs 3D

\begin{tabular}{|c|c|c|}
\hline & 2D & 3D \\
\hline 撮像時間 & 3 秒 & 3 秒 $\times 30$ 回 \\
\hline 画像再構成時間 & 9 秒 & 60 秒 \\
\hline $\mathrm{S} / \mathrm{N}$ 比 & & $<$ \\
\hline 画像コントラスト & & $<$ \\
\hline スライス方向の分解能 & & $<$ \\
\hline 任意の方向からの観察 & 可能 & 良好 \\
\hline MIP による artifact & - & + \\
\hline
\end{tabular}


MRCPでは腪胆管径は造影剤を注入しないた めにERCPよりも小さく描出される.すなわち， MRCPでは荤胆道をより生理的な状態で描出す ることができる。

\section{5. 解剖学的異常}

MRCPでは荤胆道の解剖学的異常が明瞭に描 出される.

胆道では副肝管, 胆軎管の走行異常の診断は 容易で，腹腔鏡下胆襄摘出術に伴う合併症の予 防に役立つ．膵胆管合流部も高率に描出される ので，萊胆管合流異常，とくに超音波 (US)， コンピュータ断層撮影（CT）などで診断が困 難な胆管拡張がない症例の診断に有効である。 羘管非癒合もほほ100\%診断できる.

\section{6. 胆石}

MRCPの胆石の描出率は胆襄結石 $80 \%$, 胆管

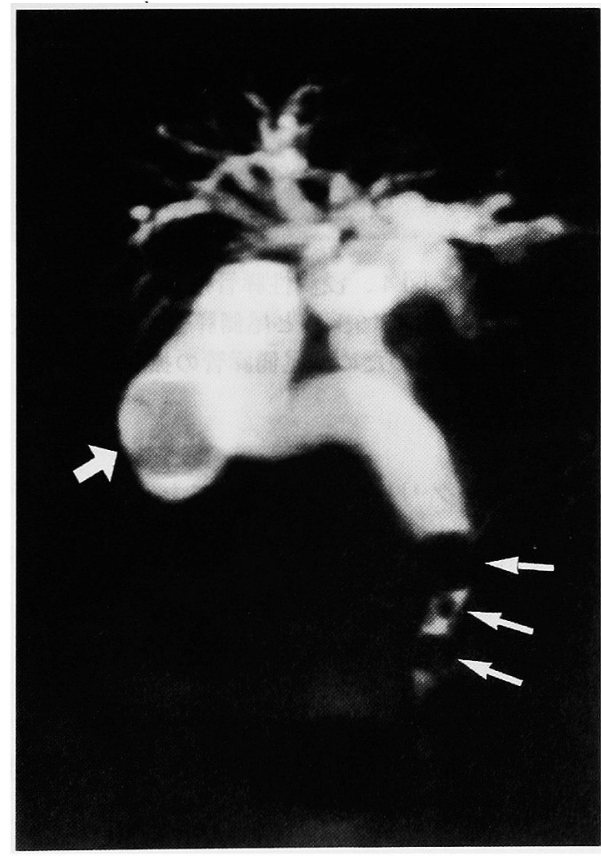

図1，胆石

胆囊と胆管に結石がみられる (矢印).
結石90〜100\%である.

胆石は高信号の胆汁中に低信号の陰影欠損と してみられる. $3 \mathrm{~mm}$ 以上の胆管結石はMRCP で診断可能である (図 1). MIP画像ではpartial volume effectによって結石が描出できない場合 がある．鑑別を要する疾患として胆管癌，血腫， 胆道気腫, 肝動脈による陰影欠損, 金属クリッ プによるartifactがある。

\section{7. 胆管癌}

胆管癌による胆管狭窄のMRCP正診率は94 98\%である．MRCPでは狭窄部の上流と下流の 胆管が描出されるので, 狭窄の範囲が正確にわ かる (図 2 )。水平進展による胆管壁不整も描 出可能である．肝門部胆管癌では直接造影で描 出困難な胆管分枝も識別できて，とくに手術の 際に問題となる尾状葉浸潤を判定するために重 要な尾状葉枝の異常の有無の描出に期待がもた れる．腪管像も同時に描出されるので胆管癌, 膵癌, 慢性膵炎, 乳頭部癌の鑑別診断ができる.

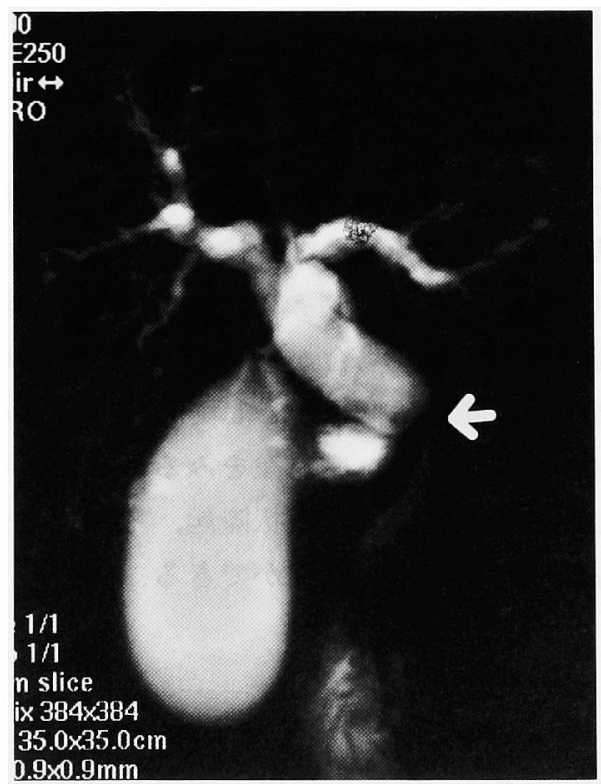

図 2. 胆管癌

中部胆管に狭窄があり (矢印), 上流の胆管は拡張し ている. 
MRCPは胆管癌の早期診断に有効である.わ れわれの経験ではMRCP施行後に無黄㾝, 胆管 非拡張, 治疾切除可能な症例の頻度が増加した。

\section{8. 慢性膵炎}

MRCPは荤管の拡張・狭窄など慢性膵炎に伴 う膵管の変化を描出することができる．膵石は 高信号の腪液中の陰影欠損としてみられるが, 膵管分枝に存在する小結石の描出は困難であ る.

\section{9. 膵囊胞}

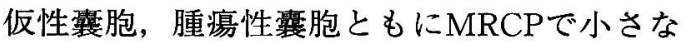
ものまで診断できる.震胞内部構造が描出され， 質的診断に有効である．槳液性囊胞腺腫では小 褧性の集簇, 粘液性褧胞腺腫 - 腺癌では隔壁 隆起が描出される．MRCPはUS，超音波内視 鏡 (EUS), CTと同等あるいはそれ以上の囊胞 の質的診断能を有する.

\section{0. 膵管内乳頭腫瘍}

MRCPは㬸管内乳頭腫瘍の診断にもっとも有 効である，ERCPでは描出困難な粘液の充満す る拡張した主㬸管および分枝が明瞭に描出され る(図 3 ). 膵管内の隆起はERCPでは粘液と 鑑別診断が難しい場合があるがMRCPでは粘液 は高信号，隆起は低信号として描出されるので 鑑別できるまま，原画像をみることによって 裻胞内の隔壁構造, 乳頭状隆起, 主膵管と分枝 褧胞の交通を認めることができる。

\section{1. 膵管癌}

MRCPでは主膵管の狭窄・閉塞と尾側膵管の 拡張が描出され, 萭管癌の診断は容易である(図 $4)$ ). $2 \mathrm{~cm}$ 以下のTS 荤癌も診断可能で, MRCP

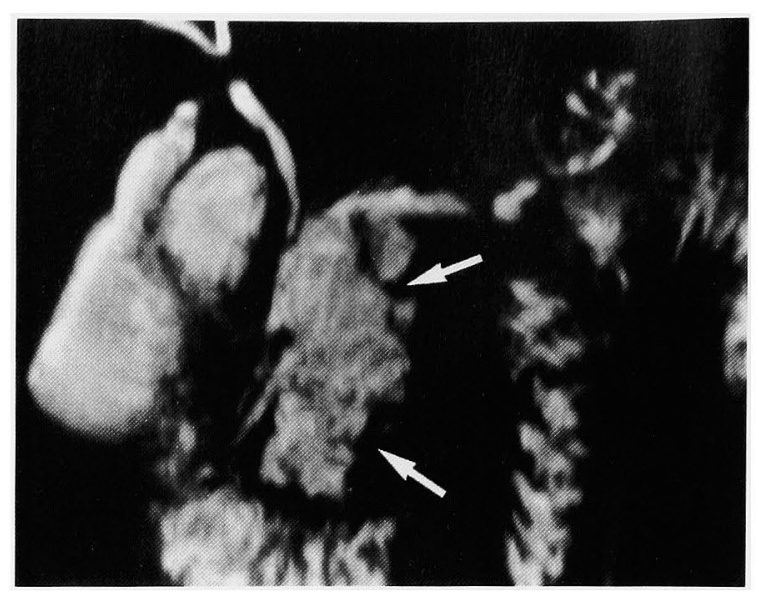

図 3，㬸管内乳頭腫湯 腪鉤部分枝の著明な拡張が認められる (矢印) . ERCP では分枝内に粘液が充満しているために造影困難で あった。

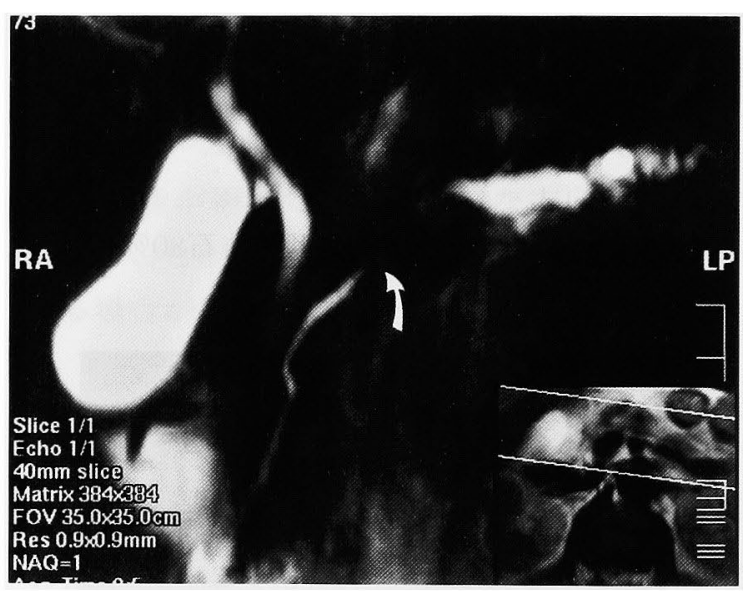

図 4、浸潤性膵管癌

膵体部主膵管の閉塞 (矢印) と尾側䔞管の拡張. ERCP では主膵管の閉塞のため, 尾側膵管の拡張は描出され ない.

は小膵癌のスクリーニング検査として有効であ る. 膵管閉塞例でも膵管の狭窄範囲がよくわか る.しかし, MRCP像から腪管癌の進展度は診 断できない.

Santorini管を含む分枝に変化が限局する症 例, 荤尾部主膵管閉塞例はMRCPの空間分解能 がERCPに比べて悪いために診断困雄な場合が ある。 


\section{おわりに}

MRCPは無侵襲で合併症がなく，短時間で膵 胆道像の描出が可能である，機器の改良による 空間分解能の向上が期待される.われわれの施 設ではMRCP施行後, 診断的ERCPの件数が大 幅に減少した。患者には福音であるが, 今後 ERCPの実技研修が問題になると考えられる.

\section{文献}

1) Wallenr B. et al: Dilated biliary tract: evaluation with MR cholangiography with a T2 weighted contrastenhanced fast sequence. Radiology $181: 805-808,1991$.

2) Morimoto K, et al : Biliary obstruction : evaluation with three-dimensional MR cholangiography. Radiology 183 : 578-580, 1992.

3) Takehara $Y$, et al: Breath-hold MR cholangio-pancreatography with a long-echo train fast spin-echo se- quence and a surface coil in chronic pancreatitis. Radiology $192: 73-78,1994$.

4) Soto JA, et al: Pancreatic duct: MR cholangio-pancreatography with a three dimensional fast spin-echo technique. Radiology 196 : 459,-464, 1995.

5) Anderson $\mathrm{CM}$, et al: Artifacts in maximum-intensityprojection display of MR angiography. AJR 154 :623$629,1990$.

6) Laubenberger J, et al: Breath-hold projection magnetic resonance cholangio-pancreatography (MRCP) : a new method for the examination of the bile duct and pancreatic duct. Magn Reson Med 33: 18-23, 1995.

7）広橋伸治，他：MR cholangiopancreatographyの基䃈と 臨床応用. 胆と滕 $16: 1123-1130.1995$.

8）崔 仁焕：胆道癌の早期診断に対する磁気共鳴画像に よる膵胆道投影法の検討. 胆道 $11: 151-157 ， 1997$.

9) Miyazaki $K$, et al: MR cholangiopancreatography using HASTE (half-Fourier acquisition single-shot turbo spinecho) sequences. AJR 166: 1297-1303, 1996.

10）崔 仁煥, 有山 襄: Magnetic resonance cholangiopancreatography (MRCP) 。 戸田剛太郎，他編 Annual Review消化器1998. 中外医学社, 1998, p31-34. 